\title{
The Eggs and Newly Hatched Young of the Common Blennies from the Plymouth Neighbourhood.
}

\author{
By \\ Marie V. Lebour, D.Sc., \\ Naturalist at the Plymouth Laboratory.
}

With 1 Figure in the Text.

The three common blennies of Plymouth are the Shanny, Blennius pholis, the Gattorugine Blenny, Blennius gattorugine, and the Butterfly Blenny, Blennius ocellaris. These have their habitat from just below high-water mark downwards. Thus, $B$. pholis inhabits the rocky pools from near high-water mark to the regions left dry by the tides; $B$. gattorugine is also to be found between tide-marks, but not so high up as B. pholis, and is more frequent in those parts uncovered by the spring tides; whereas $B$. ocellaris inhabits the deeper water and is always covered by the tide; it is frequently to be found on the dredging grounds in the region of the Mewstone and beyond the Breakwater.

In a paper by Ford (1922) the young of these three blennies are described from the earliest planktonic stage up to the time when the adult characters begin to show. The eggs of $B$. pholis and $B$. ocellaris have frequently been found and hatched out, but those of $B$. gattorugine have apparently up to the present time not been identified. In April, 1926, Mr. William Searle and Mr. Douglas Wilson, whilst collecting at Wembury, found two lots of eggs of this last species, and from one of these a few young were hatched out in the Laboratory. A brief account is given here, with figures of the eggs, of all three species, and a comparison of these with Ford's specimens from the plankton shows that they agree in every way.

\section{Blennius pholis (L.).}

Blennius pholis is to be found in rock pools, even those of the smallest size, from just below high-water mark to the upper regions between tide marks. Its eggs are deposited on the under surface of flat stones in deep crannies usually only accessible by some narrow crack through which the fish can squeeze and be safe from enemies. These crannies are covered at high water and exposed at low water, and a parent (presumably the male) guards the eggs until they are hatched. In order to see the eggs 
it is always necessary to break the surrounding rocks. The eggs and newly hatched larvæ have already been described and figured by Hefford (1910), who found them on Plymouth Breakwater. The eggs are deposited in a single layer several inches in area, each egg attached to the stone and coloured purple and gold; gold mixed with black from the eyes and body chromatophores, and purple from the yolk sac, which gradually becomes brownish as the fish grows. Each egg measures about $1.4 \mathrm{~mm}$. across (Fig. 1, b), and is spherical except at the attachment, where it is flattened so that the egg is usually really rather more than three parts of a sphere. Hefford's specimens are flatter and measure $1.6 \mathrm{~mm}$. across. Eggs still attached to the stone were kept in a tank in the aquarium in running water until almost ready to hatch, and then transferred to a plunger jar, where the larvæ emerged from the egg. On the day of hatching, in a fish $5.4 \mathrm{~mm}$. long, the yolk is already gone and teeth are present. The smallest figured by Ford is $5 \mathrm{~mm}$., and is without teeth, but otherwise agrees very well with mine. A long pointed pectoral fin, deeply pigmented with black spots, is characteristic, one or two chromatophores on the front of the head, few or none on the top, and one or two near the operculum with pigment internally along the dorsal surface of the intestine, and a few very small chromatophores ventrally towards the end of the tail. These larvæ become members of the plankton immediately after hatching and remain until at least $18 \mathrm{~mm}$. in length, the young of this size often occurring in the Plymouth plankton. Young fishes over $25 \mathrm{~mm}$. are sometimes found in the small rock pools near high-water mark. The main breeding season is in the early spring, eggs having been found from March to July, and young stages in the plankton from April through the summer.

\section{Blennius gattorugine (L.).}

Blennius gattorugine lurks in the larger rock pools lower down than $B$. photis, and also in those regions only uncovered at spring tides or never uncovered at all, but not far from the coast. It was among the rocks uncovered by spring tides at Wembury that the two lots of eggs were discovered on overhanging rocks, each batch guarded by the parent. The eggs in this case were not in such deep crevices as those of $B$. pholis and were more accessible. They were laid in a single layer like $B$. pholis and the colouring is also black and purple, but the diameter of the egg is slightly larger than any of those of $B$. pholis measured by myself, being $1.6 \mathrm{~mm}$. across and the egg is flatter, being composed of slightly more than half a sphere closely adhering to the stone (Fig. 1, a). Thus the eggs of $B$. gattorugine were more like those which Hefford attributed to $B$. pholis. And the young he hatched from these seem to be B. pholis. 
It would therefore appear that the eggs of the latter vary in shape and size, and may be extremely like those of $B$. gattorugine.

The eggs of B. gattorugine hatched with difficulty, and only a few larvæ lived long enough to draw. In the same way as $B$. photis the eggs were kept in a tank in running water until nearly ready to hatch, and then transferred to a plunger jar. The reason for the failure was probably owing to the eggs being in an early stage of development when captured.

The newly hatched fish measures $4.9 \mathrm{~mm}$. in length. Ford's smallest from the plankton. was $6 \mathrm{~mm}$. in length and rather older. They are, however, much alike, and very evidently belong to the same species. The larva from the plunger jar has a perfectly colourless tail and pectoral fin, a large brownish yolk sac, internal dark pigment in the dorsal region of the intestine from behind the eye to the anus, and a few chromatophores on the snout and on the top of the head. Ford's specimen has chomatophores ventrally along the hind end of the tail.

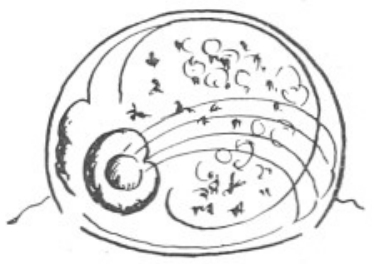

a.

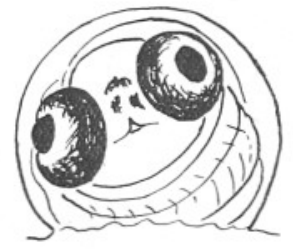

b.

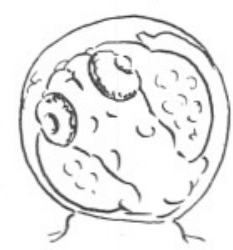

c.

FIG. 1.-a. Egg of Blennius gattorugine: $1.6 \mathrm{~mm}$. diameter. Wembury, April, 1926.

b. Egg of Blennius pholis : $1.4 \mathrm{~mm}$. diameter. Wembury, July, 1924.

c. Egg of Blennius ocellaris : $1 \cdot 12 \mathrm{~mm}$. diameter. Trawled, July, 1926 .

Older larvæ are found in the plankton up to about $20 \mathrm{~mm}$. or more. The eggs were found only in April ; young fishes are found in the plankton thoughout the summer.

\section{Blennius ocellaris (L.).}

Blennius ocellaris is well known from the rearing experiments of Garstang (1900), but the eggs and young are not figured by him. They are described from Devonshire by Cunningham (1889), who found the eggs in an old ox bone with the male parent inside, dredged by some fishermen. Ford figures a larva from Garstang's material measuring $4.6 \mathrm{~mm}$. in length, which corresponds very well with those newly hatched from the egg. The eggs are usually laid in any old shell or bottle, an empty shell of Buccinum undatum is a favourite place, or a narrow-necked bottle, and in the shell or bottle the parent fish establishes itself to guard the eggs until hatched. It is a common sight to see the fish's head peeping out from a bottle or shell aperture. The eggs are a pinkish colour, owing 
to the yolk, which changes to purple and then to brown. They are laid in a single layer inside the receptacle chosen. Each egg measures about $1.12 \mathrm{~mm}$. to $1.2 \mathrm{~mm}$. across, and is very nearly spherical, being fixed at one pole by a much smaller attachment than either of the other two (Fig. 1, c). Garstang succeeded in rearing these blennies from the egg up to quite a good size, but a very great deal of personal attention is required for such rearing. The young fish measures $4.4 \mathrm{~mm}$. in length. It has a rounded pectoral fin with thick dark masses of pigment arranged in rays, two chromatophores on the snout, a thick mass of radiating chromatophores on the top of the back and dark internal pigment over the intestine. Ventrally on the tail are a few chromatophores reaching from the centre to nearly the end of the tail. The form and pigmentation are practically the same as in Ford's figure of a larva of $4.6 \mathrm{~mm}$. in length.

Eggs are very commonly found through the late spring and summer. Young stages in the plankton throughout the summer.

It is thus seen that all the three blennies can be identified from the egg and first larval stages, all three agreeing with the early planktonic stages described by Ford.

\section{LITERATURE.}

1889. Cunningham, J. T. Studies of the Reproduction and Development of Teleostean Fishes occurring in the Neighbourhood of Plymouth. Jour. Mar. Biol. Assoc., N.S., Vol. I, 1.

1922. Ford, E. On the Young Stages of Blennius ocellaris (L.), Blennius pholis (L.), and Blennius gattorugine (L.). Ibid., Vol. XII, No. 4.

1900. Garstang, W. Preliminary Experiments on the Rearing of Sea-Fish Larvæ. Ibid., Vol. VI, 1.

1910. Hefrord, A. E. Notes on Teleostean Ova and Larvæ observed at Plymouth in Spring and Summer, 1909. Ibid., Vol. IX. 1. 